Received : 2019-06-24 Revised : 2019-06-30 Acceptance : 2019-06-30 Publish : 2019-07-22

\title{
THE INFLUENCE OF EDUCATIONAL BACKGROUND ON THE KNOWLEDGE OF DRUG USES DURING FASTING IN SAMARINDA
}

\author{
Deasy Nur Chairin Hanifa ${ }^{1}$, Ika Ayu Mentari ${ }^{1}$, Annisa Aulia ${ }^{1}$, and Azzah \\ Fatimah Zulfa ${ }^{1}$ \\ ${ }^{1}$ Department of Pharmacy, Faculty of Health and Pharmacy, Universitas Muhammadiyah \\ Kalimantan Timur, Indonesia \\ Corresponding author : $\underline{\text { dnch332@umkt.ac.id }}$
}

\begin{abstract}
At the time of fasting proper use of drugs is needed, because the schedule of taking different drugs will affect of the drug. Schedule for taking medication affects the fate of drugs in the body, because it needs to be careful in changing the schedule of taking medication. So it can be said that the need for knowledge of drug use during fasting. The aim of this study was found the influence of educational background, especially in the health and non-health fields on knowledge of drug use during fasting. This research was conducted by survey testing using Google Form, by submitting several statements regarding the knowledge of drug use during fasting which is listed in the KDUF (Knowledge of Drug Use during Fasting) questionnaire. The total value of the questionnaire is categorized into 3, namely low, moderate, and good. The results showed that the moderate knowledge category in the health group is $26 \%$ and nonhealth is $30 \%$, while the knowledge category is good for the health group at $74 \%$ and the non-health group at $70 \%$. The results of the statistical analysis showed no significant relationship between the background of health and non-health education $(\mathrm{P}>0.05)$. So it can be concluded that there is no difference in the influence of health and non-health education background on knowledge of drug use during fasting.

Keywords: Fasting, Knowledge, Health, Non-Health, KDUF
\end{abstract}

\section{INTRODUCTION}

Medication was a very important element in efforts to administer health. Most medical interventions use drugs. Therefore, there was a need for adequate availability of drugs in types and quantities, and of good quality ${ }^{1}$. Drug was a material or mixture of materials intended to prevent, reduce, eliminate, cure diseases, injuries or abnormalities of the body and spirituality in humans and animals, and to turn or beautify the human body ${ }^{2}$.

Before taking drugs, we need to know how the properties and how to use a drug that would be consumed, in this case, we need knowledge about the drug. Knowledge could be in the form of information, thought, and science. One of the things that need to be considered in taking drugs was the way and rules of drug use. In certain conditions, the way and rules for the use of drugs need to be adjusted, for example, the use of drugs in pregnant women, nursing mothers, the elderly, and when fasting.

Fasting at the time of Ramadhan was defined as worship restraint or abstinence from eating, drinking, and all things that cancel it, starting from sunrise to sunset ${ }^{3}$. The implementation of fasting was done for one month (29-30 days). Besides being prohibited from eating and drinking, consuming cigarettes and drugs is also prohibited ${ }^{4}$. But not all drugs could cancel fasting. Therefore, the importance of information needs related to drug use during fasting. In addition, the schedule for taking different 
medications would affect the effect of the drug. Schedule for taking medication could affect the fate of drugs in the body because it needs to be careful in changing the schedule of taking medication. Based on this, there needs for knowledge of drug use during fasting. So far there were still few studies relating to the use of drugs during fasting.

Everyone has a different level of knowledge. One of the factors that could influence knowledge was educational background. Educational background was an effort by humans to improve their quality of life. Educational background was known to have enough influence on one's knowledge. Therefore, in this study wanted to see the influence of educational background, especially in the health and non-health fields on the knowledge of drug use during fasting.

\section{Material and Methods}

\section{MATERIAL AND METHOD}

This type of research was cross-sectional, namely the type of research that emphasizes the time of measurement or observation of data at one time which was done on the dependent variable and the independent variable. This aims to see the relationship between variables. This research was conducted in May 2019 by conducting a questionnaire survey test using Google Form. The questionnaire used contained 14 statements regarding knowledge of drug use during fasting. This questionnaire was validated by 5 experts to examine ambiguity, understanding, and assessment of statements. The sample in this study was the Samarinda community, with inclusion criteria, namely over the age of 15 years, minimum high school / vocational education, approving informed consent, and filling out the google form in full.

\section{General procedure}

This study conducted a questionnaire survey test using Google Form, by submitting a number of statements regarding the knowledge of drug use during fasting listed in the questionnaire. Research subjects were asked to choose the "right or wrong" answer with the value of each correct answer was 1 and the wrong answer was 0 . All answers are accumulated and grouped based on total values. After the respondents filled out the questionnaire then collected and then analyzed the data.

\section{Analytical Discussion}

Data analysis in the form of bivariate analysis used Chi-Square Test with SPSS version 23 software program. The level of knowledge divided into two categories was namely less with a value of 010 and good with a value of 11-14, based on the statistical test results of the average value of the total sample of the study.

\section{RESULTS AND DISCUSSION}

Correct use of drugs could help in safe and effective treatment. But in reality, treatment often disserves the user, because it was not accompanied by an understanding of the proper use of techniques and the appropriate time of use effectively ${ }^{5}$. One of the conditions that must be appropriate in the use of drugs when fasting. The use of several drugs during fasting requires adjustments in time to consume them. Not all drugs could cancel fasting. Medications that were not used through the digestive tract could still be used, such as inhalers through the respiratory tract and injection through injection. During fasting, eating and drinking patterns would change. 
The duration of time that could be used to take medication changes from 24 hours to only 10.5 hours.

Many studies have examined the effects of individual Muslim fasting Ramadan on body metabolism, including weight gain, glucose metabolism and lipid metabolism ${ }^{6}$. One example of food can affect drugs is taking analgesics with food is clearly to reduce or prevent adverse events ${ }^{7}$. Studies assessing the effect of food on orally administered investigational drugs are an important step in establishing the optimal timing for dosing ${ }^{8}$. Because of that, knowledge is needed in consuming the medicine when fasting so that the therapeutic effects are optimal.

Respondents who participated in this study were a mixture of health and non-health education backgrounds and from different ages and levels of education. In this study, there were 285 respondents who filled out the questionnaire on the google form. Then divided into two groups based on health and non-health backgrounds. So that the total of 124 respondents included in the inclusion criteria with a total of 62 subjects in each group.

The demographic data of respondents in this study could be seen in table 1 .

Table 1. Research demographic data

\begin{tabular}{lcc}
\hline \multicolumn{1}{r}{ Category } & Total (n-124) & Frequency (\%) \\
\hline Gender & & \\
Male & 42 & 34 \\
Female & 82 & 66 \\
& & \\
Age & 94 & 76 \\
$15-20$ y & 20 & 16 \\
$21-25$ y & 10 & 8 \\
$36-30$ y & & \\
& 12 & 10 \\
Level of education & 2 & 2 \\
Senior high school & 108 & 86 \\
Diploma & 2 & 2 \\
Bachelor & & \\
Master & & \\
\hline
\end{tabular}

In this study, testing was carried out using the Knowledge of Drug Use Fasting (KDUF) questionnaire consisting of 3 domains with 14 item statements, which can be seen in table 2 .

Table 2. Questionnaire about Knowledge of Drung Use Fasting (KDUF)

\begin{tabular}{cl}
\hline Number & \multicolumn{1}{c}{ Statement } \\
\hline 1 & Mengkonsumsi obat oral (tablet, kapsul, sirup) dapat membatalkan puasa. \\
2 & Penggunaan obat yang diletakkan di bawah lidah dapat membatalkan puasa. \\
3 & Menggunakan obat suntik pada lengan tidak membatalkan puasa. \\
4 & Pemberian nutrisi melalui obat suntik pada lengan tidak membatalkan puasa. \\
5 & Penggunaan obat kumur dapat membatalkan puasa. \\
6 & Obat yang diresepkan untuk diminum sebelum makan dapat dikonsumsi 15 menit \\
& sebelum makan selama bulan puasa. \\
& Obat yang diresepkan untuk diminum setelah makan dapat dikonsumsi 5-10 menit \\
& setelah makan selama bulan puasa. \\
\hline
\end{tabular}




\begin{tabular}{cl}
\hline 8 & Jarak minum antar obat tidak mempengaruhi khasiat obat. \\
9 & Obat yang digunakan 1 kali sehari dapat dikonsumsi saat sahur dan berbuka puasa. \\
10 & Obat yang digunakan 2 kali sehari dapat dikonsumsi saat sahur dan berbuka puasa. \\
11 & Obat yang diresepkan 2 kali sehari dapat dikonsumsi sekaligus 2 tablet pada saat \\
& sahur atau berbuka. \\
12 & $\begin{array}{l}\text { Obat yang digunakan } 3 \text { kali sehari dapat dikonsumsi saat sahur (04.30), saat } \\
\text { berbuka (18.30), dan saat akan tidur di malah hari (23.30). }\end{array}$ \\
$13 \quad \begin{array}{l}\text { Obat yang dikonsumsi } 4 \text { kali sehari sebaiknya diganti dengan obat yang dapat } \\
\text { dikonsumsi 1-2 kali sehari dengan dosis yang sama. }\end{array}$ \\
Pada pasien diabetes yang masih mampu menjalankan puasa dianjurkan untuk \\
memilih obat dengan pemberian 1 kali sehari dan dikonsumsi saat berbuka puasa.
\end{tabular}

In this study assessing the level of knowledge of respondents to the use of drugs during fasting. The results of the study could be seen from the total value of answers on the KDUF questionnaire. Then it is categorized into 2, less and good. The results of the level of knowledge of respondents based on educational background in this study could be seen in table 3 .

Table 3. Level of Knowledge based on Educational Background

\begin{tabular}{lcccc}
\hline Category & \multicolumn{4}{c}{ Educational background } \\
\cline { 2 - 5 } & $\begin{array}{c}\text { Health } \\
(\mathbf{n = 6 2})\end{array}$ & $\begin{array}{c}\text { Percentage } \\
(\boldsymbol{\%})\end{array}$ & $\begin{array}{c}\text { Non Health } \\
(\mathbf{n = 6 2})\end{array}$ & $\begin{array}{c}\text { Percentage } \\
(\boldsymbol{\%})\end{array}$ \\
\hline Less & 16 & 26 & 30 & 48 \\
Good & 46 & 74 & 32 & 52 \\
\hline Total & 62 & 100 & 62 & 100 \\
\hline
\end{tabular}

Table 3 show the results of the analysis of the questionnaire used to determine the effect of educational background on knowledge of drug use during fasting. Less knowledge categories in the health group were $26 \%$ and non-health were $30 \%$, while the categories good of knowledge in the health group were $74 \%$ and the non-health groups were $52 \%$. To see the relationship of educational background to knowledge of drug use during fasting, Chi-Square Test statistical analysis was used. The results showed of the statistical test obtained P-value of $0,016(\mathrm{P}<0,05)$. Therefore, it could be concluded that there was significant difference in the influence of health and non-health education background on knowledge of drug use during fasting. Based on the results of the study it could be concluded that the educational background was a factor that determines the level of one's knowledge.

Facilities technology, environment, and learning opportunities related to health science could affect a person's knowledge, especially related to care during the fasting month. Even though the government had conducted socialization regarding the use of drugs during the fasting month, in the fact the results have not been maximized. Because there still many people from non-health backgrounds who lack knowledge related to treatment during the fasting month. 
In this study also looked at the relationship between gender and knowledge shown in table 4

Table 4. Level of Knowledge based on Gender

\begin{tabular}{|c|c|c|c|c|}
\hline \multirow[t]{2}{*}{ Category } & \multicolumn{4}{|c|}{ Educational background } \\
\hline & $\begin{array}{c}\text { Male } \\
(n=41)\end{array}$ & $\begin{array}{c}\text { Percentage } \\
(\%)\end{array}$ & Female $(n=62)$ & $\begin{array}{c}\text { Percentage } \\
(\%)\end{array}$ \\
\hline Less & 20 & 49 & 26 & 31 \\
\hline Good & 21 & 51 & 57 & 69 \\
\hline Total & 41 & 100 & 83 & 100 \\
\hline
\end{tabular}

Table 4 shows the results of the questionnaire analysis used to determine the influence of gender on knowledge about drug use during fasting. The category of less knowledge in the male group is $41 \%$ and the female group is $31 \%$, while the category of knowledge in the male group is $51 \%$ and the female group is $69 \%$. This result was in accordance with the statement of psychologists, who suggested that women had better memories and knowledge than men? Women had knowledge more accurate, more detailed, and more consistent than men ${ }^{\mathbf{1 0}}$. Nonetheless, the results of this study were incompatible with several previous studies where patients with male sex had a higher average score of knowledge than women ${ }^{\mathbf{1 1}, \mathbf{1 2}}$. Things that can affect, namely the number of male and female respondents who were not the same, where male respondents only amounted to 41 people and 83 female respondents. To see the relationship of gender to knowledge of drug use during fasting, Chi-Square Test statistical analysis was used. The results of statistical tests obtained a $\mathrm{P}$ value of $0.09(\mathrm{P}>0.05)$. Therefore, it could be concluded that there was no significant difference in gender influence on knowledge about drug use during fasting.

\section{CONCLUSION}

The results of this study concluded that educational background (health and non-health) determined knowledge about drug use during fasting $(\mathrm{P}<0.05)$, but gender influence does not determine knowledge about drug use during fasting. Based on the results of the study it could be concluded that the educational background was a factor that determines the level of one's knowledge.

\section{ACKNOWLEDGEMENT}

This study was funded by Department of Pharmacy, Universitas Muhammadiyah Kalimantan Timur, Indonesia. 


\section{REFERENCES}

1. Fatokun, O. Mohamed, I.M. and Azmi, H.. Journal of Applied Pharmaceutical Science. 01 (09), 35-37. (2012)

2. Joenoes N.Z., 2001, ARS Prescribendi Resep Yang Rasional, Edisi 1, hal.16, Airlangga University Press, Surabaya

3. Firmansyah, M. Adi. Pengaruh Puasa Ramadhan pada Beberapa Kondisi Kesehatan. 2015. CDK-230/ vol. 42 no. 7.

4. Natalia, Andrena, Rr. Sulistiyaningsih. Review : Puasa Ramadhan Dan Diabetes Melitus. (2018). Farmaka Suplemen Volume 16 No1

5. Hening Pratiwi, Nur Amalia Choironi, Warsinah. (2017). doi: 10.26874/kjif.v5i2.107

6. Firmansyah, M. Adi. Tata Laksana Diabetes Melitus saat Puasa Ramadhan. 2013. CDK204/ vol. 40 no. 5. (2013)

7. Robert Andrew Moore,1 Sheena Derry,1 Philip J. Wiffen1 \& Sebastian Straube. (2015). doi:10.1111/bcp.12628

8. Susanne A. Johansson1,Mikael Knutsson,Maria Leonsson-Zachrisson1, and David P. Rosenbaum. (2017). doi: 10.1002/cpdd.341

9. Bratama, 1987 Pengertian-pengertian Dasar dalam pendidikan Luar biasa, Jakarta: Departemen Pendidikan dan Kebudayaan, 76.

10. Kartono, K., 1989, Psikologi Wanita (jilid 1); Mengenal Gadis Remaja dan Wanita Dewasa”, Bandung, 193-196.

11. Al-Maskari, F., El-Sadig, M., Al-Kaabi, J.M., Afandi, B., Nagelkerke, N., and Yeatts, K.B. PLoS ONE, 8: e52857. (2013).

12. Fatema, K., Hossain, S., Natasha, K., Chowdhury, H.A., Akter, J., Khan, T. BMC Public Health, 17: 1-10. (2007). 